\title{
FIXED-TIME ARTIFICIAL INSEMINATION IN DAIRY EWES RAISED IN FIELD CONDITIONS IN ARGENTINA
}

\author{
[Inseminação artificial em tempo fixo em ovelhas leiteiras criadas extensivamente na Argentina]
}

\author{
Laura Simonetti $^{1 *}$, Gloria María Lynch ${ }^{1}$, Mercedes Mc Cormick ${ }^{1}$ \\ ${ }^{1}$ Cátedra de Rumiantes Menores, Facultad de Ciencia Agrarias, Universidad Nacional de Lomas de Zamora, Buenos Aires, \\ Argentina.
}

\begin{abstract}
Modern systems of sheep production are directed towards intensification, being in this line the adoption of artificial insemination. The objective was to compare two protocols of fixed-time artificial insemination (FTAI) in dairy ewes managed under field conditions in Buenos Aires province, Argentina. Twenty four two-tooth Milchschaf $x$ Texel ewes, aging 18 months, were synchronized with intravaginal sponges plus $300 \mathrm{IU}$ eCG and cervically inseminated with fresh semen either once at $54 \mathrm{~h}$ (Group A) or twice at 48 and $60 \mathrm{~h}$ (Group B) after sponge removal. Additionally, a second experiment was performed to detect the estrus onset; thus, 23 Milchschaf $\mathrm{x}$ Texel ewes were synchronized as previously described and estrus was detected at 6-h intervals by teaser rams. The pregnancy rate was higher in B than in A (B: 50.0\% vs. A: 9.1\%; P < 0.05). In the group exposed to teasers, $91.3 \%$ of the ewes came into estrus from 24 to $36 \mathrm{~h}$ after sponge removal, with an interval to estrus averaging $30.6 \pm 1.0 \mathrm{~h}$. Based on both type of mucus mostly observed and data of estrus outcome, it could be suggested that the difference in effectiveness between protocols would be related to an earlier rather than to a double insemination. In conclusion, this study provides information on the application of FTAI in dairy ewes reared rangeland in Argentina.
\end{abstract}

Keywords: Sheep, reproduction, AI, FTAI, synchronization.

RESUMO - Sistemas modernos de produção de ovinos são direcionados para a intensificação, sendo nesta linha a adoção da inseminação artificial. O objetivo foi comparar dois protocolos de inseminação artificial em tempo fixo (IATF) em ovelhas leiteiras criadas em condições de campo na provincia de Buenos Aires, Argentina. Vinte e quatro ovelhas Milchschaf x Texel com "pinças permanentes", de 18 meses de idade, foram sincronizadas com esponjas intravaginais e $300 \mathrm{UI}$ de eCG e inseminadas por via cervical com sêmen fresco. As IATF foram realizadas uma vez às 54 h (Grupo A) ou duas vezes às 48 e 60 h (Grupo B) após a retirada da esponja. Foi realizado um segundo experimento com 23 ovelhas Milchschaf x Texel, as quais foram sincronizadas como descrito anteriormente e seus estros foram detectados em intervalos de $6 \mathrm{~h}$ por rufiões. A taxa de prenhez foi maior em B do que em A (B: 50,0\% vs A: 9,1\%; P < 0,05). No grupo exposto a rufiões, 91,3\% das ovelhas entraram em estro 24-36 h após a retirada da esponja, com um intervalo médio ao estro de 30,6 $\pm 1,0 \mathrm{~h}$. Com base no tipo de muco mais freqüentemente observado e nos resultados da apresentação de estro, pode ser sugerido que a diferença na eficácia entre protocolos estaria mais relacionada com a precocidade do estro em relação aos tempos pré-estabelecidos para as inseminações do que propriamente o número de inseminações. Em conclusão, este estudo oferece informação sobre a aplicação da IATF em ovelhas leiteiras criadas nas pastagens da Argentina.

Palavras-Chave: Ovinos, reprodução, IA, IATF, sincronização.

\footnotetext{
*Correspondence author. Email: simonettilaura@yahoo.com.ar
} 


\section{INTRODUCTION}

Sheep have been historically important in Argentina, mainly exploited for wool and followed by meat. They have been widely raised under extensive systems in which animals are subjected to the natural variations of the environment. Initially developed in Buenos Aires province, sheep production was further displaced to other more marginal regions.

Nowadays sheep are seen as an alternative to improve the profitability of farms, especially those of small size. Given the advantages offered by Buenos Aires province, based on its agro-ecological conditions and proximity to the main consumption centers, there is interest in adding dairy to the other more traditional sheep products. Among the principal exploited genotypes of dairy purpose there are Milchschaf and Pampinta (a local breed derived from Milchschaf) pure or crossed, followed by Texel and Manchega. Although dairy genotypes have little involvement in the racial composition of the flocks, there is growing interest in their breeding (Suárez \& Busetti, 2009).

Modern systems of sheep production are directed towards intensification of management, being in this line the adoption of assisted reproductive technologies (ARTs). Among them, artificial insemination (AI) is the oldest and most widely used and one of the most important (Faigl et al., 2012). Taking into account that dairy sheep is an incipient activity in Argentina, this technology could immediately contribute to its genetic improvement. AI is practiced either after estrus detection or at a predetermined time following a synchronization treatment (Abecia et al., 2011). This last alternative, named as fixed-time AI (FTAI), is the most practical method (Menchaca et al., 2005) since it avoids heat detection, which implies not only the need of teasers but the more frequent movement of the flock, predisposing specially in rangeland flocks to health, nutritional and management problems. Among the hormonal protocols available for estrus synchronization of ewes in a FTAI program, the most widely used is the progestagen and eCG combination (Abecia et al., 2011). There are several factors that could impact on the effectiveness of a FTAI program (breed, age, management, season, methods of synchronization and insemination and type of semen, among others) (Kukovics et al., 2011; Faigl et al., 2012), thus the technique needs to be properly adjusted according to each circumstance. Indeed, Donovan et al. (2004) informed the difficulty of applying the same time of insemination in different breeds, probably due to variability in the times of estrus onset and ovulation, among other problems (Quirke et al., 1981; Cueto \&
Gibbons, 1997; Makawi \& Manahil, 2007; Manes et al., 2010; Padilha et al., 2011; Moradi Kor et al., 2012).

So far, research in our country has been focused on the most traditional systems (wool and meat). In AI the majority of published information was generated in Merino ewes exploited for wool in other area of the country (south of Argentina, Patagonia) (summarized in Gibbons \& Cueto, 2012). Some local studies have aimed to breed dairy genotypes out of season (Catalano et al., 2005, among others) to provide milk during autumn-winter, the more demanding period. However, as reared rangeland, the most economically efficient management is to breed our flocks in the autumn breeding season (Mc Cormick et al., 2007).

Consequently, the objective of this study was to compare two protocols for fixed-time artificial insemination in dairy ewes managed in field conditions in Buenos Aires, Argentina.

\section{MATERIAL AND METHODS}

\section{Location of experiment}

The study was carried out in a dairy sheep farm located in Uribelarrea $\left(35^{\circ} 06^{\prime} \mathrm{S}\right.$ and $\left.58^{\circ} 53^{\prime} \mathrm{W}\right)$, Buenos Aires province, Argentina. The area is characterized by an annual rainfall of about 1100 $\mathrm{mm}$ and an average daily ambient temperature ranging from $12^{\circ} \mathrm{C}$ in July to $24^{\circ} \mathrm{C}$ in January.

\section{Experimental animals}

Milchschaf $x$ Texel ewes, dry, two-tooth, averaging 18 months of age and $55 \mathrm{~kg}$ of body weight, were used in this experiment.

Throughout the year, animals were managed altogether and maintained in good health. They were kept under natural field conditions and fed good quality grasses composed of implanted (Avena sativa, Sorghum bicolor L. Moench) and native pastures (Trifolium repens, Lolium multiflorum, Lotus tenuis), plus a supplementary ration during most critical periods.

\section{Experimental design Experiment 1}

During the breeding season of autumn (early March) 24 females were synchronized with $60 \mathrm{mg}$ medroxyprogesterone acetate (MAP)-impregnated polyurethane sponges inserted deep into the vagina and left in place for 14 days. At sponge withdrawal, ewes were treated with 300 IU eCG administered intramuscularly and assigned to two groups of FTAI: a) Group A $(n=12)$ : inseminated once at 54 $\mathrm{h}$ after sponge removal, and b) Group B $(\mathrm{n}=12)$ : 
inseminated twice at 48 and $60 \mathrm{~h}$ after sponge removal.

Semen from a Milchschaf ram with proven fertility was collected using an artificial vagina and evaluated for its characteristics (volume, motility, concentration). Then, the ejaculate was diluted 1:1 (semen:diluent, v/v) with UHT skim milk extender and maintained at $30^{\circ} \mathrm{C}$.

Cervical artificial insemination was performed within $1 \mathrm{~h}$ after semen collection. Having located the entrance to the cervix by means of a speculum equipped with a light source, a dose of $0.1 \mathrm{ml}$ of fresh diluted semen ensuring about 150 million motile sperm was deposited as deep as possible using an insemination gun.

Sixty days after insemination, ewes were examined by ecography to identify those actually pregnant and to count the number of fetuses.

\section{Experiment 2}

Additionally, in order to gain useful information for FTAI, 23 Milchschaf $x$ Texel ewes similar to those submitted to insemination, were synchronized as previously described in Experiment 1.

Estrus onset was checked at 6-h intervals from pessary removal and for a period of $96 \mathrm{~h}$ by means of teaser rams.

\section{Data and statistical analysis}

Table 1. Reproductive performance of Milchschaf x Texel ewes subjected to two protocols of FTAI (Group A: inseminated once at $54 \mathrm{~h}$; Group B: inseminated twice at 48 and $60 \mathrm{~h}$ )

\begin{tabular}{lcc}
\hline Variables & Group A & Group B \\
\hline Fertility (\%) & $9.1(1 / 11) \mathrm{B}$ & $50.0(6 / 12) \mathrm{A}$ \\
Fecundity (\%) & $18.2(2 / 11) \mathrm{b}$ & $58.3(7 / 12) \mathrm{a}$ \\
Prolificacy & $---------1.28(9 / 7)$---------
\end{tabular}

Values with different capital letters within a row differ significantly at $\mathrm{P}<0.05$.

Values with different lowercase letters within a row differ significantly at $\mathrm{P}<0.10$.

Single insemination is the most used method since it simplifies AI and allows doubling the number of ewes per ejaculate. Although there is no consensus regarding to the optimal time for cervical FTAI after progestagens/eCG, several authors inseminate at 52-57 h (Donovan et al., 2004; Manes et al., 2010; Olivera-Muzante et al., 2011; Viñoles et al., 2011). Thus, time of $54 \mathrm{~h}$ for single AI was selected on the basis of the literature. However, intervals to estrus and ovulation depend upon breed, age, body condition and protocol used to synchronize, among others. Regarding to breed differences, Donovan et al. (2004) reported that the timing of cervical AI (at $57 \mathrm{~h}$ ) was adequate for Finn ewes but inappropriate for other breeds.
On the base of the information of Experiment 1, reproductive performance of the groups was calculated, involving the variables: fertility (pregnant ewes/inseminated ewes), prolificacy (fetuses/pregnant ewes) and fecundity (fetuses/inseminated ewe). Data regarding to fertility and prolificacy were statistically analyzed by Fisher's exact test. Differences were considered significant at $\mathrm{P}<0.05$ and $\mathrm{P}<0.10$.

In Experiment 2, the following variables were recorded: interval from sponge removal to estrus presentation (time to estrus onset; mean \pm SEM; $h$ ), percentage of females showing estrus at each time of estrus detection (estrus distribution; \%) and percentage of females that came into estrus within $96 \mathrm{~h}$ after sponge removal (estrus rate; \%).

\section{RESULTS AND DISCUSSION}

Data on reproductive performance after FTAI (Experiment 1) are presented in Table 1. One ewe lost the sponge during treatment, so it was excluded from the analysis. As shown, the pregnancy rate for the double insemination group (Group B) was $50.0 \%$, significantly higher than the $9.1 \%$ registered for the group inseminated once (Group A) (P < 0.05). Because only one ewe of Group A became pregnant, prolificacy could not be analyzed by groups. So, prolificacy without discriminating on group was 1.28 , meaning that $28.5 \%$ of ewes gestated twins as none of them carried triplets.
Fertility could be improved with the practice of a double insemination, so that the second AI prevents from the possibility that first one is practiced too early in relation with ovulation. Also, in case of poorly concentrated ovulations, double FTAI could be beneficial. However, its vantage might be impaired by the stress caused with the second management of the ewes. Considering that double insemination could be beneficial when fertility is depressed, one could hypothesize that, as in the current study females were two-tooth of age, category that is usually destined to first matting in our country, they are favored. However, we inferred that the difference in effectiveness between protocols would be related to an earlier rather than to a double insemination, based on our observations of both type of mucus and estrus outcome. 
Indeed, cervical mucus observed in most of the ewes when practicing the insemination at $48 \mathrm{~h}$ was typical of the first half of estrus (stringy, abundant and crystalline), while the mucus observed at $54 \mathrm{~h}$ and specially at $60 \mathrm{~h}$ seemed to correspond to advanced estrus (scare, milky and dense flux). Similar to us, the effect of time of estrus at AI was evident for Muñoz et al. (2002), who obtained pregnancy rates of $47.4 \%$ when inseminating at type 1 estrus (red colored vagina, light and stringy flux) and of only $11.1 \%$ at type 3 estrus (poorly red colored vagina, scare, milky and dense flux).

Regarding to estrus outcome (Experiment 2), the group treated with the same protocol and submitted to estrus detection resulted tightly synchronized, coming $91.3 \%$ of ewes into estrus from 24 to $36 \mathrm{~h}$ after removal of devices (Figure 1). Mean time to estrus onset was $30.6 \pm 1.0 \mathrm{~h}$, which agrees with those reported in other breeds, such as Galway (31.2 $\pm 1.5 \mathrm{~h}$; Quirke et al., 1981), woolness crossbreed ewes (34 \pm 2.7 h; Padilha et al., 2011) and
Kermani ewes $(30.3 \pm 4.4$ h; Moradi Kor et al., 2012). Contrastly, Makawi \& Manahil (2007) obtained a longer interval to estrus onset $(49.4 \pm 1.9$ h) in Desert ewes treated similarly. In Argentina, Cueto \& Gibbons (1997) informed marking activity from 36 to $72 \mathrm{~h}$ after MAP and 300 IU eCG in multiparous Merino ewes. Other work in our country in multiparous Texel ewes treated with sponges plus $200 \mathrm{IU}$ eCG showed an average of estrus at $42.0 \mathrm{~h}$ (Manes et al., 2010). It is pertinent to note the lower concentration of heats reported in the two last cited works compared to that observed herein.

Indeed, it could be hypothesized that if the high concentration of heats was accompanied by a high concentration of ovulations, thus inseminating at 60 $\mathrm{h}$ would have been unnecessary. Moreover, further studies are needed to elucidate if earlier times of FTAI than $48 \mathrm{~h}$ would improve pregnancy.

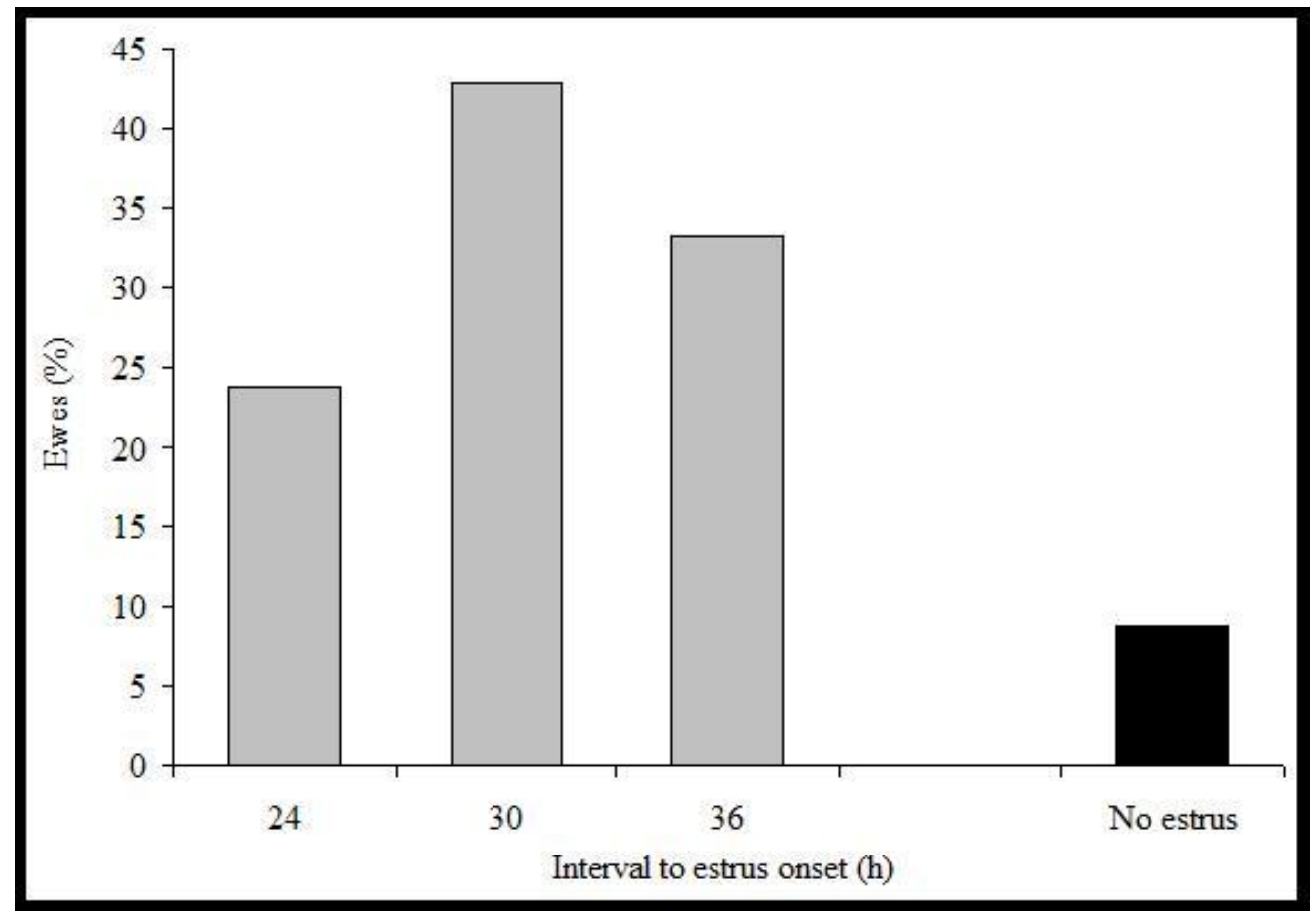

Figure 1. Distribution of estrus synchronized with progestagen plus eCG in Milchschaf x Texel ewes $(n=23)$.

The literature contradicts results following double FTAI. Pioneer studies demonstrated no benefit of two inseminations even in ewe lambs (Langford et al., 1982; Langford, 1986). Langford (1982) reported similar pregnancy rates by inseminating once at 54 or $57 \mathrm{~h}$, or twice at 54 and $60 \mathrm{~h}$, but not once at $60 \mathrm{~h}$, suggesting this was a late time for insemination. Menchaca et al. (2005) found that pregnancy rate of Merino ewes resulted higher after single FTAI at $48 \mathrm{~h}$ than at $54 \mathrm{~h}$, and was not affected by the double practice ( 48 and $54 \mathrm{~h}$ ). These authors hypothesized that the early insemination suited better with time of ovulation and with the period that takes sperm transport in the genital female tract. On the other hand, the vantage of the double FTAI was evident for AcritopoulouFourcroy et al. (1982). In this line, a study in anestrus Merino ewes under field conditions found that two inseminations (at 48 and $60 \mathrm{~h}$ ) gave better conception and lambing rates than one (at $54 \mathrm{~h}$ ) (Greyling et al., 1988). More recently, an experiment in fat-tailed ewes inseminated during late breeding season either once (at 54-56 h) or twice (repeated at 6-8 h) (Emsen et al., 2008) 
reported that double insemination did favor lambing rate and prolificacy, questioning if either the higher dose of spermatozoa or the repeated insemination accounted for such differences. Karagiannidis et al. (2001) concluded that the best time for double FTAI depended on the breed, being at 48 and $72 \mathrm{~h}$ for Chios and Chios x Vlachiki breeds, but at 48 and $60 \mathrm{~h}$ for Vlachiki.

Protocols for synchronization frequently incorporate a low dose of eCG to obtain a more precise synchronization of estrus and ovulation (Abecia et al., 2011). As it is known, eCG affects ovulation rate and thus the incidence of multiple births, which could predispose to pregnancy toxaemia and to lamb mortality. In Argentina, sheep breeding is mainly carried out extensively, being vital to avoid these problems by adjusting the eCG dose. Records from the same farm in ewes of this age not treated with eCG show a similar prolificacy to that obtained herein, suggesting that 300 IU eCG did not stimulate additional follicular development.

\section{CONCLUSIONS}

The study provides information on FTAI in dairy ewes under field conditions in Buenos Aires, Argentina. Reproductive performance was higher when inseminating at 48 and $60 \mathrm{~h}$ than at $54 \mathrm{~h}$ after sponge removal/eCG. Based on both type of mucus mostly observed and estrus outcome, it could be suggested that the difference in effectiveness would be related to an earlier rather than to a double insemination.

\section{ACKNOWLEDGEMENTS}

The authors are thankful to Ing. Zoot. Guillermo Graffigna for his technical assistance in the experimental assays.

\section{REFERENCES}

Abecia J.A., Forcada F. \& González-Bulnes A. 2011. Pharmaceutical control of reproduction in sheep and goats. Vet. Clin. Food Anim. 27: 67-79.

Acritopoulou-Fourcroy S., Pappas V., Plecaris G. \& Zervas N. 1982. Synchronization of oestrus in ewes with Provera sponges/PMSG, prostaglandin F2alpha or the prostaglandin analogue, ICI 80996, and fertility following natural mating. Reprod., Nutr., Dév. 22: 345-354.

Catalano R., González C., Teruel M., Cabodevila J. \& Callejas S. 2005. Efecto del estado fisiológico y del porcentaje de raza Frisona sobre la respuesta reproductiva de ovejas en servicio de primavera. InVet. 7: 99-105.

Cueto M. \& Gibbons A.E. 1997. Efecto de la dosis de PMSG en la inseminación artificial intrauterina sistemática o con detección de estros. ITEA. 18: 440-442.
Donovan A., Hanrahan J.P., Kummenb E., Duffy P. \& Boland M.P. 2004. Fertility in the ewe following cervical insemination with fresh or frozen-thawed semen at a natural or synchronised oestrus. Anim. Reprod. Sci. 84: 359-368.

Emsen E., Gimenez Diaz C.A., Yaprak M., Koycegiz F., Kutluca M. \& Aslan F.A. 2008. Factors affecting the reproductive performance of fat-tailed ewes inseminated with laparoscopy in the late breeding season. Anim. Reprod. 5: 30-33.

Faigl V., Vass N., Jávor A., Kulcsár M., Solti L., Amiridis G. \& Cseh S. 2012. Artificial insemination of small ruminants - A review. Acta Vet. Hung. 60: 115-129.

Gibbons A. \& Cueto M. 2012. Research, development and implementation of artificial insemination and embryo transfer in sheep and goats. Spermova 2: 1-5.

Greyling J.P.C., Greeff J.C., Brink W.C.J. \& Wyma G.A. 1988. Synchronization of oestrus in sheep of low-normal mass under range conditions: The use of different progestagens and PMSG. S. Afr. J. Anim. Sci. 18: 164-167.

Karagiannidis A., Varsakeli S., Karatzas G. \& Brozos C. 2001. Effect of time of artificial insemination on fertility of progestagen and PMSG treated indigenous Greek ewes, during non-breeding season. Small Rumin. Res. 39: 67-71.

Kukovics S., Gyoker E., Nemeth T. \& Gergatz E. 2011. Artificial insemination of sheep - Possibilities, realities and techniques at the farm level, cap.3, p.27-50. In: Milad Manafi (ed.) Artificial insemination in farm animals. Rijeka.

Langford G.A. 1982. Influence of PMSG and time of artificial insemination on fertility of progestogen-treated sheep in confinement. J. Anim. Sci. 54: 1205-1211.

Langford G.A. 1986. Influence of body weight and number of inseminations on fertility of progestogen-treated ewe lambs raised in controlled environments. J. Anim. Sci. 62: 1058-1062.

Langford G.A., Ainsworth L. \& Wolynetz M.S. 1982. Reproductive response of progestogen-treated sheep in confinement to a single and double insemination. J. Anim. Sci. 54: 12-17.

Makawi S.A. \& Manahil Z.A. 2007. Fertility response of Desert ewes to hormonal oestrous synchronization and artificial insemination using fresh diluted semen. J. Anim. Vet. Adv. 6: 385-391.

Manes J., Fiorentino M.A., Kaiser G., Hozbor F., Alberio R., Sanchez E. \& Paolicchi F. 2010. Changes in the aerobic vaginal flora after treatment with different intravaginal devices in ewes. Small Rumin. Res. 94: 201-204.

Mc Cormick M., Arzubi A., Simonetti L., Rodrigo G., Santos I., Roberi J.L., Real Ortellado M., Lynch G., Ganchegui M. \& Cañón M. 2007. Estudio de la producción, industrialización y comercialización de carne y leche ovina como alternativas a las producciones agropecuarias actuales de la región Sudeste de la Provincia de la Pampa. Ed. Ministerio de la Producción de la Provincia de La Pampa - CFI, Buenos Aires. 234p.

Menchaca A., Pinczak A. \& Queirolo D. 2005. Storage of ram semen at $5{ }^{\circ} \mathrm{C}$ : effects of preservation period and timed artificial insemination on pregnancy rate in ewes. Anim. Reprod. 2: 195198.

Moradi Kor N., Mohammadi Khanghah K. \& Veisi A. 2012. Efficiency of short time protocols based on combined FGA, PGF2 $\alpha$, GnRH and eCG treatments on oestrus synchronization and reproductive performance of Kermani ewes during the breeding season. Int. J. Biol. Med. Res. 3: 1966-1970. 
Muñoz C.M., Parraguez V.H.G. \& Latorre E.V. 2002. Efecto del tiempo de inseminación artificial después de la detección de celo sobre la tasa de preñez en ovinos Corriedale. Agric. Téc. 62: 616-623.

Olivera-Muzante J., Fierro S., López V. \& Gil J. 2011. Comparison of prostaglandin and progesterone-based protocols for timed artificial insemination in sheep. Theriogenology. 75: 1232-1238.

Padilha R.T., De Magalhães D., Maia-Junior A., Brasil A.F. \& De Araújo A.A. 2011. Efeito de diferentes dispositivos intravaginais na sincronização estral e taxa de gestação em ovelhas deslanadas submetidas à IATF via cervical superficial com sêmen refrigerado. Rev. Bras. Ciênc. Agrár. 6: 538-543.
Quirke J.F., Narran J.P. \& Gosling J.P. 1981. Duration of oestrus, ovulation rate, time of ovulation and plasma $\mathrm{LH}$, total oestrogen and progesterone in Galway adult ewes and ewe lambs. J. Reprod. Fert. 61: 265-272.

Suárez V.H. \& Busetti M.R. 2009. Encuesta descriptiva sobre prácticas de ordeño, manejo y producción en el tambo ovino. Vet. Arg. 26: 1-19.

Viñoles C., Paganoni B., Milton J.T.B., Driancourt M.A. \& Martin G.B. 2011. Pregnancy rate and prolificacy after artificial insemination in ewes following synchronisation with prostaglandin, sponges, or sponges with bactericide. Anim. Prod. Sci. 51: 565-569. 